\title{
On the problem of historical regression.
}

The cases of decline in ancient civilizations are dramatic instances of historical regression. Many scholarly works have been devoted to the phenomenon but all proposed various scenarios may be divided into two groups - natural catastrophes and barbarian invasions. Scientists are sure that the causes of the decline of civilizations can only be exogenous because they are deeply convinced that progress is always good. From their point of view, people's natural desire for progress can only be stopped by force, by the forces of nature or by savages. However, in all cases of regression, the destruction of a civilization is endogenous and spontaneous.

Hence, is the statement correct that progress is always good for the population? Probably no one will argue that the transition to more intensive methods of land use has signified progress. However, for example, during the transition to agriculture, the life of the population deteriorated so much that even their life expectancy was reduced. Ethnographers have collected a huge amount of evidence showing that with the transition to more intensive land use, labour productivity decreased (Sahlins, Boserup). According to my calculations, during the transition from slash farming or forest-fallow system to arable farming, labour productivity decreased by about five times (Alexakha, 157). In pre-industrial societies, the vast majority of the population was employed in subsistent agriculture, therefore, when transit to more intensive land use, these people had to work more and more. Indeed, the researches of ethnographers has shown that hunters and gatherers usually work no more than 3 hours a day, and often less (Sahlins, 17). Moreover, their work - hunting, fishing, picking wild plants - is considered entertainment in modern society. Nomads also work little, if at all.

Nevertheless the transition to more intensive land use happened. But it happened only forcibly when the density of population exceeds some critical level that may be called critical population density that is the highest possible population density in given natural conditions at a given stage of land use intensity. As the land of every country is limited, it may be considered as a reservoir with capacity equal to the critical population density times the land area. The ratio of the capacity of the reservoir to the critical density is the reservoir's critical coefficient. The reservoir is full when the population density is equal to the critical density, i.e. the critical coefficient is equal to 1 . Further population growth led to starvation.

Thus, man can intensify the use of land and so raise the critical population density, but as a consequence labour productivity will diminish. In order to avoid famine, the population is subjected to harder and more regular work. Therefore, with every stage in the intensification of land use, the population is compelled to be more disciplined, hard-working, and persistent, so the level of population development will advance.

Although many scholars do not consider themselves Marxists, they have adopted the basic theoretical preposition of Marx about surplus product. They believe that in the process of development of a pre-industrial society, productivity of labour in agriculture grew, as a result of which the worker could produce more than he and his family needed, the so-called surplus product. Thanks to the emergence of the surplus product, it became possible the emergence of social stratification, that is, people not employed in the production process, and emergence of the state. Since the facts gathered by ethnographers contradict this scheme, these facts are ignored. In fact, labour productivity in agriculture during the development of pre-industrial society per hour or per day will diminish but due to increased discipline and persistency of population the labour productivity per year will increase owning to augmentation of number of working hours.

State may come into existence only when the level of population development becomes high enough, which corresponds to arable farming. Therefore hunters and gatherers, shifting agriculturists or nomads cannot found a true state. Their upper limit is a tribe or union of tribes only. State for them is impossible because these forms of labour do not 
generate a high enough level of development. Hunters and gatherers, shifting agriculturists and nomads simply cannot support a state social order - they lack the discipline. In addition, the state arises only when the critical coefficient becomes high enough so that the population has a need to maintain order in society.

So when population density exceeds the critical level the population begins to starve. Such a situation cannot endure, making some change to the society inevitable. The possible changes may be described by three laws of reservoirs.

The first law is: the population pressure in the reservoir is counterbalanced by pressure on neighbouring reservoirs. When the critical coefficient of a reservoir is greater than 1, the population will try to seize neighbouring land in order to avoid the intensification of land use or starvation. The neighbours resist, but if the population pressure on their reservoir is insufficient, they will lose the struggle and the conquerors will settle in. The critical coefficient in the conquerors' reservoir diminishes and progress there stops. The first law explains the causes of migrations in pre-industrial societies.

The second law of reservoirs is: the smaller the reservoir, the more quickly it is filled, but also the smaller it is, the less the potential for progress. According to the first law, the population of neighbouring reservoirs confronts each other. For the state of equilibrium between adjacent reservoirs, their population military abilities should be approximately equal. Therefore, large reservoirs always have a lower population density than smaller ones. Therefore, the more capacious a reservoir is, the more time it takes for it to fill up. But progress occurs only when the reservoir is full. So the population of a very capacious reservoir will have a constant level of development for a long time and lag behind the populations of less capacious reservoirs. The latter are filled more quickly and consequently develop faster.

The third law of reservoirs is: a rise in the critical coefficient causes the growth of social tensions, the acceleration of economic development, and the centralization of power. A decrease in the coefficient produces the reverse processes.

The critical coefficient increases as a result of rising population density. As more and more people become redundant in agriculture, they look for jobs in trade and industry, and the division of labour deepens. The shortage of means of subsistence stimulates the intensification of agriculture. As a result, economic development quickens. However, not all can find employment, and more and more beggars, vagabonds, and robbers appear. The worsening shortage of food causes discontent among the broad masses, triggering social tensions. Moreover, the critical coefficient usually rises within the whole agglomeration of reservoirs, so international tensions also increase. In order to control these processes, the society needs a strong central power. However, if for some reason the critical coefficient diminishes; free land becomes abundant so everybody can work on it, reversing all the abovementioned processes.

Let us apply the instruments of the proposed theory to some of the best-known cases of historical regression.

\section{The Minoan civilization.}

The first civilization in Europe was the Minoan, which arose on Crete in the 2700s BCE. The island is not large, with an area of $8,336 \mathrm{~km}^{2}$. And it is mountainous, the range crossing it from east to west having peaks higher than $2000 \mathrm{~m}$. Agriculture is possible only in valleys and plateaus, which are quite insignificant in size, such as the Lasithi Plateau $(11 \mathrm{~km}$ east-to-west and $6 \mathrm{~km}$ north-to-south). The largest plain on Crete is Messara Plain, which measures only $50 \mathrm{~km}$ east-to-west and $7 \mathrm{~km}$ north-to-south. In short, to use our terminology, Crete has a very small-capacity reservoir. 
The Minoan culture had all the features of civilization. There were enormous palaces decorated with magnificent frescos. The palaces had several floors and sewer systems. Crete was the first place in Europe where writing was used: first Cretan hieroglyphics, then syllabic Linear A. Paved roads connected the chief palace in Knossos with other parts of the island. Findings of many objects of Minoan manufacture in mainland Greece, Egypt, Anatolia, Syria, Cyprus and Mesopotamia have demonstrated the wide trading contacts of the Minoans. Scientists date the decline of Minoan civilization to the middle of the 15th century BCE (Dickinson, 73).

In 1930 the Greek archaeologist Spyridon Marinatos first hypothesized that the decline of the Minoan civilization was due to the eruption of the volcano of Thera. It seemed evident that the cause of decline had to be some exogenous event that stopped the natural development of the civilization. But subsequent research has found many reasons to question this assumption. First, the exact date of the eruption has still not been determined.

Archaeologists had naturally placed it at between 1500 and 1450 BCE (Sivertsen, 25) because by that time the decline had already set in. But radiocarbon dating puts it between 1627 and 1600 BCE (Friedrich et al., 548; Betancourt, 45-49). Moreover, it has been determined that the layer of ash that fell on Crete after the eruption was no more than $5 \mathrm{~mm}$ deep, and many Minoan remains have been found above the ash layer and the possible tsunami level (Callender). Such a covering of ash would have been too small to cause the decline of a civilization. Major earthquakes were not uncommon on Crete. When they happened and palaces were destroyed, the Minoans replaced them with still more grandiose ones, as happened in 1600 BCE. It is worth noting that at the time of crisis in 1450 BCE, while most palaces were destroyed, the central palace in Knossos remained largely intact (Welwei, 12-18). The hypothesis that the decline of Minoan civilization was due to the eruption of Thera cannot explain these facts.

It has also been suggested that the Minoan civilization was destroyed by invaders (Hood, 58). According to some scholars, these invaders were Greeks who arrived on the island from mainland Greece. Indeed, after the middle of the 15th century BC in Crete, radical changes are being observed in the material culture, including the practice of burials. New elements come from mainland Greece. However, all these changes occur after the signs of the deep decline of the Minoan civilization have become indisputable.

We can explain the Minoan decline by methods, proposed in this paper. Crete's small reservoir was filled very early, that is why the first European civilization arose here, as postulated by the second law of reservoirs. However, the reserves for further intensification of agriculture were soon exhausted; in fact, it is the judgment of most archaeologists that by $1450 \mathrm{BCE}$ all the land on Crete suitable for agriculture was in use (Dickinson, 69).

According to the first law of reservoirs, one way out of these difficulties would have been migration, if possible. And in fact archaeologists have uncovered extensive evidence of migration of Minoans on islands in the Aegean, Palestine, and the western coast of Asia Minor (Snodgrass, 2000, 308; Tartaron, 21). According to Strabo, Miletus was first founded and fortified by Cretan colonists $(14,1.6)$. Archaeologists have found in Miletus fragments of Minoan-style frescoes and texts of linear A (Greaves, 66).

It is of prime importance that Herodotus recorded a popular legend about a campaign of Cretans in Sicily and their foundation of a colony in southern Italy, leaving Crete depopulated (Hist. 7, 170-171): "Presently all the Cretans except the men of Polichne and Praesus were bidden by a god to go with a great host to Sicania [Sicily - author's note]. Here they besieged the town of Camicus... Presently, since they could neither take it nor remain there because of the famine which afflicted them, they departed. However, when they were at sea off Iapagia [southern Italy - author's note], a great storm caught and drove them ashore. Because their ships had been wrecked and there was no way left of returning to Crete they 
founded there the town of Hyria, and made this their dwelling place... The Praesians say that when Crete was left desolate, it was populated especially by Greeks, among other peoples". Although Herodotus did not explain why the Cretans had left their island, this popular legend corresponds exactly to the archaeological findings and the reconstruction of the events according to our theory of historical progress.

When a significant part of the population emigrated from Crete and the critical coefficient fell, the state became unnecessary for those who remained. The social structure collapsed, the upper social strata became ordinary citizens. The artisans who used to build palaces, painted frescos and made objects of art ceased to be paid by the upper strata of society and the creation of new monuments of civilization stopped. Greeks with the mainland of Greece move to Crete after most of the inhabitants left, which is confirmed by archaeological finds and the legend transmitted to us by Herodotus.

\section{The Harappan civilization.}

The Harappan civilization arose in the Indus valley in the 27th century BCE. By that time the Indus people had migrated from villages to cities and the Early Harappan communities had become large urban centres, probably the biggest in the world at the time. Their quality of town planning, sewerage and drainage were far more advanced than in any contemporary urban sites (Chakrabarti, 206). The Harappan people were the first to construct irrigation canals in the Indus valley. Their earliest examples of written language date to the 3rd millennium BCE. Goldsmiths, engravers and potters achieved high levels of skill. Excavations have uncovered large quantities of fine gold, silver, stone and bone necklaces, beads, rings, bracelets and so on. Copper and bronze were widely used. There is substantial evidence that the cities of the Indus valley civilization traded with South India, Afghanistan and Iran (Asthana, 271-285).

From the 18th century BCE, however, archaeologists have found only indications of decline. In Mohenjo-Daro, one of the largest Harappan cities, all large public houses were abandoned and fell into ruin, and the population took their bricks to build small new houses. Potter's kilns had appeared in the main streets (Wheeler, 111-113). By around 1700, most of the cities were abandoned, and there was a substantial decline in population. The principal features of the regression were:

1. All towns were abandoned.

2. Written language was forgotten.

3. Ceramics became much more primitive and were produced without the wheel.

4. Metal was used much more rarely.

5. Luxury items were much rarer.

6. Items of foreign trade vanished.

7. Depopulation.

8. No sign of invaders.

In 1953 Sir Mortimer Wheeler ascribed the decline of the Harappan civilization to an invasion of Aryans from Central Asia. In the opinion of specialists, however, the decline of the Harappan civilization, simply cannot be explained by invasion. First, the onset of the Harappan crisis antedates any sign of the new comers (Bongard-Levin, Ylyin, 107-108). Second, the decline was endogenous in nature. The cities were not destroyed but abandoned and fell into ruin only afterwards. Significantly, the crisis came first in the central parts of the Indus civilization, and only after a century or two did the peripheral areas to the east and south begin to collapse (Bongard-Levin, Ylyin, 92). Apart from barbarian invasion, other scholars have suggested that the regression was due to changes in the course of the river and drought, or conversely by flood, or by deforestation (Knipe ). 
The Harappan was the most geographically extensive of all the early civilizations. The beginnings of the civilization (the Amri culture), some scholars believe, were in the lower Indus valley, on the Sindh plain. Sindh is arid area, with little land suitable for agriculture. In keeping with the second law of reservoirs, this region developed faster. As the reservoirs filled, the population moved up the Indus in Punjab. The Harappan centres were not the first in the Indus valley to be abandoned. Archaeologists have uncovered earlier towns that were abandoned and went to ruin (Kulke, Rothermund, 23-25).

Thus the Harappan population migrated and constantly developed new lands until the entire Indus basin was filled. Then they began to migrate eastward to the Ganges basin and, on a much smaller scale, southward. In accordance with the first law of reservoirs, the first migration was from the central regions of the civilization, where the critical coefficient was higher. Once the population density had fallen, in accordance with the third law, the regression began. The outlying regions retained their level of development for a time. The Aryan tribes only moved into the depopulated Indus basin much later after the Harappan civilization had collapsed.

\section{The civilization of ancient Maya.}

The whole territory of the Mayan civilization can be divided into three parts. The southern part, with the exception of a narrow coastal plain Soconusco, is occupied by mountains with the highest elevations over 3,800 $\mathrm{m}$ in the Sierra de los Cuchumatanes. In the coastal plain Soconusco it rains heavily, over $3000 \mathrm{~mm}$ annually. In the mountains rainfall averages about $2000 \mathrm{~mm}$ per year (Johnson, 47). To the north from the mountains is the second part of the Maya territory - the South Lowlands. The lowlands receive 2000-3000 $\mathrm{mm}$ of rain per year. Due to the rich volcanic soil and heavy rainfalls, lush rainforests, rivers, marshlands and lakes occupy the South Lowlands. Further north the third part is situated the North Lowlands in Yucatan. Here is less than $2000 \mathrm{~mm}$, in some places even less than $500 \mathrm{~mm}$ of rainfalls annually (Johnson, 50). Besides porous limestone bedrock, which formed the Yucatan peninsula, quickly draws surface water. Therefore the vegetation of the North Lowlands is low forest and dense scrub.

Linguists believe that a single proto-Mayan language, before its divergence, existed somewhere in the mountains (Sharer, Traxler, 28). After $2000 \mathrm{BC}$ the language diverged forming the major Mayan language groups. Consequently, from this time began the Mayan migrations from the mountains to the lowlands. Archaeologists consider this time the beginning of the Preclassic period (c. 2000 BC - 250 AD). During the Middle Preclassic Period (1000-350), first cities appeared. The Maya civilization reached its apogee in the Classic period (250-950 AD). The political structure of the civilization was a group of citystates who feuded and entered into alliances with each other. The Maya cities were of considerable size, the largest ones numbered above 100 000. Maya created unique architectural style. Perhaps the most known are the Mayan stepped pyramids with temples atop. Maya built large and highly decorated palaces and developed original art. They used a complex system of hieroglyphic writing that was the most advanced in the pre-Columbian Americas.

The most flourishing in the Classic period were cities of the South Lowlands. The most populous and rich cities were situated here; they had the greatest political and military power. However between the 8th and 9th centuries the Mayan cities of the South Lowlands declined and were abandoned. The collapse of southern Maya cities considered to be one of the greatest unsolved mysteries in history of ancient civilization.

As one would expect, most scientists see the causes of urban decay of the South Lowlands in external factors, such as of foreign invasion, epidemic diseases or change of trade routes. But archaeologists do not find any vestiges of intruders, except only of Toltec. 
However the significant Toltec intrusion dates well before the Late Classic collapse. Besides the cities were not destroyed by war but abandoned. History knows examples when epidemics may kill a huge number of people as it was in Europe during the Black Death. But history does not know any example when an epidemic lead to deep depopulation of a territory for centuries. No matter how large the number of victims of the epidemic, the population is always restored after some time. There is no evidence that cities of the South Lowlands depended so heavily on foreign trade that its termination could lead to their depopulation. Thus, all these theories cannot explain the Late Classic collapse. Therefore, as it seems, the theory of drought has become the most popular today.

The drought theory holds that severe and long drought brought about the Late Classic decline. However the fall of the southern Maya cities coincided with the rise of a northern Mayan region. Precisely at the time when cities of the South Lowlands were declined and depopulated, the Northern Lowlands cities entered the period of heyday and increasing political power. The great northern polity of Chichen Itza arose by the eighth century A.D. and had its apogee during the ninth and tenth centuries A.D. when it briefly united much of the Maya region. The rise of Chichen Itza occurred precisely when the southern metropolises fell (Andrews, Andrews, Robles, 151-15). If severe and long drought really happened then the arid north should have suffered more from it than a damp rainforest zone. In other words, according to the drought theory Maya went away from the drought to where it was stronger.

What happened according to the proposed theory of progress? Maya practised forestfallow agriculture; in Mesoamerica they called it milpa cultivation. During dry season vegetation on a plot was chopped down and dried up. Before beginning of wet season the dry wood was burned and sowing was done without land cultivation. The field can be used for one to two, maximum three years. Fallow period lasted 8-10 years. (Jonson, 54). The human capacity of the Southern Lowlands was not large because in the forest zone the forest-fallow system is possible only on well-drained plots. During the wet season when it rains heavily water linger on the soil surface in areas with poor drainage and that will kill the crop, therefore, there are not so many lands suitable for the forest-fallow system in the South Lowlands.

We have many signs that from the Middle Preclassic period the critical coefficient in the south grew. The population was concentrated in the cities because in conditions of constant wars it was safer. Under the influence of a growing critical coefficient, according to the third law, the power of the rulers increased. The divine king had become the centre of political power. The authority of the ruler was such that he could mobilize population in executing large-scale construction of pyramids, temples and palaces. Due to high critical coefficient population was obedient and disciplined that allowed the higher social strata to extract sufficient income to support an army of craftsmen and officials. As a result, art flourished, writing originated and developed. The population continued to grow, the peasants were forced to intensify land use, they practised raised fields, terracing, intensive gardening, but this reduced labour productivity.

Finally, according to the first law in the 9th century BC large-scale migrations from south to north began. Not all of the population left the Southern Lowlands, but the critical coefficient fell abruptly and this destroyed the social structure. The peasants no longer needed kings and cities. At the same time, in the north, the critical coefficient increased and cities began to grow here. However, in this time the critical coefficient did not was as high as it was before due to increasing territory. Therefore individual rule of divine king was replaced by a ruling council formed from elite. Some weakening of the central government led to a reduction in monumental buildings with hieroglyphic writing in the north (Andrews, Andrews, Robles, 151-15). The Maya territory has no natural restrictions on migration; 
therefore mass migrations took place here repeatedly before and after the 9th century, that every time resulted in the depopulation and decline of previously flourishing cities.

\section{The Mycenaean civilization.}

The Mycenaean civilization in peninsular Greece originated in the 16th century BCE, a millennium after the Minoan one. This conforms to our second law of reservoirs, as the capacity of Crete's reservoir is evidently much smaller than that of the reservoirs in southern and central Greece where the Mycenaean civilization arose. The golden age of the Mycenaean civilization was from the 15th to the 13th century. Many Mycenaean centres were fortified, and the fortifications were most impressive. The stronghold of Tiryns had two rings of thick walls and a subterranean passage. Archaeologists usually use the word cyclopean for the Mycenaean fortifications, as the walls were built of colossal stones. Such fine and powerful fortification is indicating that the population had a high critical coefficient and a long history of warfare. The archaeological findings provide conclusive evidence of the stratification of Mycenaean society. The graves of Mycenaean chiefs and aristocrats are full of gold, silver, ivory and excellent examples of decorative art, while the graves of the common people display only a few, poor possessions.

Starting in 1450 BCE the Mycenaeans used written language (linear B) adopted from Crete and adapted for Greek. Examples of linear B writing have been found in many locations in Mycenaean Greece, sometimes in considerable quantity. At Pylos, a thousand clay tablets with characters of linear B were excavated, suggesting that literacy in Mycenaea was comparatively widespread for those times. The Mycenaean centres traded with many countries: Egypt, Mesopotamia, Cyprus, southern Italy, Sicily, Sardinia and the Iberian peninsula (Schofield, 71-72).

However, by the start of the 12th century the Mycenaean civilization had collapsed. The big fortified cites were abandoned, the clay tablets disappeared, the art and decorative handicrafts progressively deteriorated. Some forms, such as frescoes, disappeared altogether, while other crafts - jewellery, engraving, fretwork - became more and more primitive. If in the burial places of the Mycenaeans of the 14th and 13th centuries archaeologists often found objects from foreign lands, such as stained glass, gold, ivory, scarabs from Egypt, or seals from Mesopotamia, in those of the 12th century such finds are increasingly rare, and by the 11 th century they disappear entirely (Snodgrass, 2000, 325). While the ceramics dating from the first half of the 12th century counted 108 different kinds of vessel, the 11th century shows only 12 types (Snodgrass, 34), and very crudely made. One archaeologist has said this work was really Stone Age style (Desborough,1972, 41). Metal ware had become rare, and the excavations turned up mostly small articles, such as arrowheads, knives and rings. Armour, helmets, silver and bronze tableware, and diadems had simply disappeared. In some places, the population had gone back to making knives and arrowheads from obsidian (Snodgrass, 2000,382 ). The graves of the 11th century testify to a minimal degree of social stratification, because the burial inventories were standard and very poor (Kraiker, Kübler , 9).

Thus, the picture of all of Greece in the 11th and 10th centuries BCE is one of profound regression, which lasted until the 8th century. Archaeologists have termed this period "the Dark Ages of Greece". What was the cause of the regression? The standard answer has been invasion by barbarian tribes. It was once thought that the Dorian tribes had destroyed the Mycenaean civilization. Later, however, many scholars came to reject the theory of Dorian invasion (Desborough,1964, 252; Mylonas , 224, 406; Finley, 61; Cartlidge, 5).The Dorian tribes actually came to Greece long after the collapse of the Mycenaean civilization like the Aryan tribes only moved into the depopulated Indus basin after the Harappan civilization had collapsed as well as Greeks after depopulation of Crete. 
Besides, in some locations there is no trace whatever of intruders. On the face of it, however, it is difficult to refute the theory of invasion, because without it the regression is apparently inexplicable. The search continues for unknown barbarian tribes that are assumed to have destroyed practically all of Greece while leaving no vestiges (Desborough 1964, 237; Snodgrass 2000, 305). Other scholars, however, recognize that this thesis cannot explain the Mycenaean collapse (Dickinson, 309).

Interestingly, while some palaces of Mycenaean civilization were destroyed by fire and show signs of having been taken by storm, others were simply abandoned and decayed over time, as on Crete. If the Mycenaean civilization collapsed due to barbarian invasion, how can we account for the fact that some fortified places survived the end of the 13th century by more than a century (Sandars, 230), as was the case in Attica, where the Acropolis of Athens avoided destruction? Similarly, some Mycenaean regions continued to prosper, such as the Ionian islands, the northwestern Peloponnese, parts of Attica and a number of Aegean islands (Freeman, 126).

It is of importance that the very severe depopulation of Greece that took place during the collapse of the Mycenaean civilization. Whereas archaeologists have found 320 places in Greece that were inhabited in the 13th century BCE, there were only 130 in the 12 th century and a mere 40 in the 11th (Snodgrass 2000,364)! And the size of the locations that were inhabited was sharply reduced as well (Snodgrass 1980, 20). Scholars have documented the drastic decrease in population in many Mycenaean regions (Freeman 2014, 126), and archaeologists indicate that the Greek population was smaller in the 11th than in the 21thcentury BCE (Snodgrass 2000, 367).

The principal features of Mycenaean regression, then, were:

1. Decay of fortified towns. Some fortified places were not destroyed but abandoned.

2. Written language was forgotten.

3. The ceramics became much more primitive and potter's wheels fell into disuse.

4. Metalware was much rarer, replaced by stone.

5. Luxury items, art and cult objects almost completely vanished from use. Little if any sign of social stratification appears.

6. Objects of foreign trade vanished.

7. Depopulation

8. No sign of invaders.

The characteristics of the decline of the Mycenae civilization are identical to those of Harappan.

From the standpoint of our model, what happened here? The critical coefficient of Mycenaean Greece had become too high, while neighbouring lands had lower coefficients. According to the first law of reservoirs, in such cases migration is inevitable, and migrations did in fact take place. People travelled east and southeast. Excavations at Miletus offer evidence that Mycenaeans had settled there already by 1450 BCE (Tartaron, 21), and Hittite texts indicate the presence of Ahhiyawa in western Anatolia from 1400 (Bryce, 361) "Ahhiyawa" is a Hittite translation of "Achaeans" as in Homer's poems, or of Mycenaean Greeks in the modern sense. We know about Greek raids on western Asia Minor from the Iliad. Scholars now date the Trojan War to the mid-13th century BCE (Castleden, 213). However, the mass resettlement of Greeks did not come until later. The bulk of migrants settled on the west coast of Asia Minor, and scholars date the foundation of most of these settlements to the 12th or 11th century (Snodgrass 2000, 373), exactly when Mycenaean Greece was being depopulated. Mycenaeans also migrated to Cyprus and the Levantine coast (Tartaron, 18), but most went to the western coast of Asia Minor, which in fact was to become one of the centres of ancient Greek civilization. It is worth noting that it was 
precisely here that Homer's poems were preserved, while in European Greece they were forgotten.

In short, mass migration produced severe depopulation and drove the critical coefficient down. And what followed, according to the third law of reservoirs, was social and economic regression. Thucydides, in writing about the primordial life of the Greek tribes, spoke of "continuous movement" (Thuc. 1.2). Some scholars have maintained that in the 12th -11th centuries the population of Greece had gone back to nomadic or semi-nomadic life (Starr, 80). This would correspond precisely to the third law of reservoirs, the change over to more extensive land use thanks to its higher labour productivity. The Dorian tribes came into Greece long after the collapse of the Mycenaean civilization, because there was abundant abandoned land.

\section{Decline of Roman state.}

From all cases of historical regression the decline of Roman state was the most colossal and best studied. Historiographers have about 200 hypotheses explaining the fall of the Roman Empire, but not one of these hypotheses has become generally accepted. Let us see how the proposed theory explains this case of historical regression.

The first European full-scale civilisation aroused in Greece which is situated on a peninsula that prevents migration and hence, according to our first law, quickens progress. The second smallest Mediterranean peninsula is the Italian, and this is where the next European centre of development was inevitably situated. The largest Mediterranean reservoir, the Iberian peninsula, in antique period simply took too long to fill up. So it was of course not mere chance that ancient Italy was the centre of a world empire.

It is impossible to understand the development of Italy without considering its geography. The geography is such that in the South of Italy human capacity was minimal in antiquity (comparison with modern Italy is irrelevant, as we are now dealing with an industrial economy; in preindustrial Italy, the absolute majority of the population were subsistence farmers). Moving northwards, capacity increased: it was greater in Campania than in Calabria and Basilicata, greater in Latium than in Campania and greater in Tuscany than in Latium. The greatest human capacity was found in the Po river plain and its extension in Venetia, the capacity increasing from west to east (although in ancient times the plain was not considered be Italy at all but a part of Gaul). These features were crucial to Italian historical development.

In accordance with the second law of reservoirs, the earliest centres of development were the Greek colonies in southern Italy and Sicily, where capacity was the least. Later, the centre shifted to the middle of the Apennine peninsula. At that time, Latium and the neighbouring territories had the highest population density in all of Italy. By time of the Second Latin War (340 BCE), the Roman state had an area of 3095 sq. km (Beloch, 70) and a population of 250,000 (Liv. XI, 19). This gives a population density of 80 per square kilometre. A hundred years later, according to Polybius (Pol., II, 24), in $225 \mathrm{BCE}$, during the Gallic invasion, the Italian tribes had differing numbers of men able to bear arms: Umbrians 20,000, Etruscans 50,000, Lucanians 30,000, Iapigians and Messapians 66,000. Assuming that men able to bear arms made up 20 to 25 percent of the population and that today's Italian provinces correspond roughly to the tribal areas of ancient Italy, we can calculated the following population densities: Umbrians, 12 per $\mathrm{km}^{2}$, Etruscans 11, Lucanians 15 , Iapigians and Messapians 17. All these densities are far lower than those of Latium and Campania.

The population density of Middle Italy demanded very intensive agriculture. The ancient authors reported that 2 ugers was enough to support one Roman citizen (NH, 18,2; Varr. 1,10). This means 10-12 ugers (2.5-3 hectares) for a family of 5 to 6 members. These conditions produced a population that was disciplined, persistent and diligent, because in 
order to survive the peasantry had to work harder and harder. Early Roman legends tell of fierce, ceaseless warfare with neighbouring peoples. These wars stemmed from the very high critical coefficient. Such conditions could be withstood only thanks to social unity and selflessness. And these were precisely the characteristics that enabled the Romans to conquer Italy and to create a world power.

The third law of reservoirs predicts that the growth of population above critical density will result in the centralization of power, the emergence of social tensions and the acceleration of economic development. All of these phenomena are found in the historical development of Italy. It is certainly no accident that the periods of especially fierce social struggle in Rome were followed by large expansions of the territories under Roman control, as happened between around 390 and $360 \mathrm{BCE}$, during the struggle of the plebeians for the limitation of occupied fields. It is widely held that the social struggle in Rome was practically always due to a shortage of land, or in our terms by a high critical coefficient. From the midfourth to the mid-third century, Rome's territory increased eight-fold, as the rising critical coefficient triggered social tensions, which where conditions permitted issued forth in territorial expansion. By now the Roman colonization of Italy (350-157 BCE) had begun; a total of 53 colonies were founded, and the excess population moved away from Rome and its environs. No wonder that period from the late fourth to the mid-second century was one of social peace.

At this stage, the unification of Italy was inevitable. It is out of the question that the Italic tribes pledged fealty to Rome only out of fear of the Roman legions. Rather, the unification of Italy was certainly advantageous for all the Italics. Among other things, it entailed the cessation of tribal wars.

The acceleration of economic development from the end of the 4th century is evident. The first roads, new public buildings, the first aqueduct and the introduction of coinage all tell us that the Roman economy was growing.

There are differing views of demographic processes in Italy in the last two centuries BCE. After Karl Julius Beloch published "Das italische Bund unter Roms Hegemonie" (Italian Union under Rome's hegemony), some scholars began to suggest that the Italian peasant population was declining (Toynbee; Brunt), based on the census figures of the first century. But other scholars maintained that the population was growing in the countryside as well as in the towns (Launaro; Lo Casio). From the standpoint of our model, there are many facts to corroborate the scenario of population growth in Italy in the last two centuries BCE. The period of social peace that marked the colonization of Italy from the early third to the mid-second century gave way to a series of episodes testifying to growing social tension.

First was the movement of poor Romans for land reform, headed by the Gracchi brothers from 130-120 BCE. The bitter struggle for land shows that the critical coefficient was high. Certainly, the allotment of land to poor farmers by a land reform commission lowered the coefficient, but not for long, and by the end of the second century the social struggle had broken out again. The social tensions took the form of a struggle between populares and optimates.

That the main issue of the social struggles in the first century BCE was land has long been clear to historians (Rostovtzeff, 24). After the reforms of Marius, the Roman army was no longer a peasant militia but a professional military force, compensated by pay during service and a plot of land after retirement. Earlier, during the age of bloody warfare between the Italic tribes, every peasant knew he had to defend himself and his family. With the unification of Italy under Rome, this factor was eliminated, while population growth constantly drove the redundant farming population off the land. In preindustrial societies the sole cause of the emergence of landless peasantry is population growth, because in these societies peasants engage in subsistence farming and are practically immune to the market 
mechanism while the division of land between the heirs inevitably leads to the fact that the plots of the peasants become too small for the existence of the family.

By the end of the 2nd century BCE, the many landless young peasants in Rome constitute evidence of a high critical coefficient. These landless peasants joined the legions of Marius, as they would later enrol in those of another Roman military commander. Tacitus quotes Tiberius to the effect that only paupers and the homeless joined the army voluntarily (Tac., Ann., IV ,4,2). The consequences of Marius' reform are well known. The veterans wanted land as compensation for their military service, and only a military chief could offer this. As a result, the veterans supported their own commanders in the struggle for power. The rest of Roman republican history, until the dawn of the Empire, consisted in the power struggle among military chiefs.

This lay still in the future, however. To my mind, the most important event of the time was the War of the Allies, which was triggered by the very high critical coefficient among Italics. This is a particular of considerable importance - during the war with Hannibal, virtually all of Rome's allies in Italy had remained loyal. What changed during the century that followed? Population growth had made land scarce, and the shortage was especially acute for the allies, as the Roman policy of allotment produced inequality of land ownership between Roman citizens and the allies. Therefore, as Appian observes, "The Italic peoples slipped little by little into pauperism" (C.B. 1,7). The Italian allies demanded political equality with Roman citizens, and the material realization of this was equality in the land allotment. Significantly, the heart of the Italic uprising was in the Apennines, where the capacity of the reservoirs was smallest and the critical coefficient highest. After the end of the War of the Allies, the Lex Ulia and the Lex Plautia Papiria ensured that Italy was united in the sense that practically all Italics had equal right to land allotment. But by this time, in the first century BCE, the entire Italian reservoir was full. The uprisings of Lepidus and Catiline and the subsequent civil wars between Roman military chiefs (Marius and Sulla, Caesar and Pompey, Octavian and Marc Antony) are a good indication of a very high critical coefficient in Italy.

The wars between military chiefs represented a pure power struggle, as no social or economic reforms were proposed. The majority of the Roman people took no part on either side, as for them it was totally indifferent who would control the state. They needed order and peace, and the only way out was to put an end to anarchy and confer power on a single man. Thus power was centralized, in accordance with the third law of reservoirs. The result was the Roman Empire.

The land redistributions, which constituted one important consequence of the civil wars, demonstrate that the supply of free land in Italy was now totally exhausted. Obviously, redistribution could not change the critical coefficient, and the only possible solution was migration of the population to conquered provinces outside Italy. And this is precisely what happened. In this sense the foundation of the Empire marked a turning point in Roman history. First Caesar resettled 80,000 Roman citizens outside Italy (Suet., D.J., 42) and only 40,000 in Italy (App. B.C., 2,35; Suet. D.J, 20). With the end of civil warfare Augustus had to demobilize an enormous number of veterans. We know from "The Deeds of Augustus" that he allotted land to 120,000 veterans, not only in Italy but in also in Africa, Sicily, Macedonia, Spain, Achaea, Asia, Syria, Gallia Narbonensis, and Pisidia (RGDA, 29).

And the colonization of the provinces continued under Augustus' successors as well. The levelling of the critical coefficient in Italy and the provinces had begun, in accordance with the first law of reservoirs. The barbarians practiced very extensive forms of land use the forest-fallow system and cattle breeding on natural pastureland. So the population density there was very low. Roman colonists brought with them much more intensive agriculture, increasing the critical population density many-fold. The Roman provinces were thus 
converted into reservoirs with very low critical coefficients, while their human capacity was enormous.

As we have seen, the process always involves diminishing activity in all fields and subsequent regression (third law). The consequence was an easing of the social tension in Rome. The century of social struggle from 130 to $30 \mathrm{BCE}$ had come to an end. The period from the first century BCE through the first century CE was the peak of development of the Roman state. But ancient Rome was a preindustrial society, and this meant that economic growth had to be accompanied by falling living standards for the majority of the Italian population. It is doubtful that the living standards of ordinary Romans improved in the late Republic and early Empire, because this coincided with the greatest territorial expansion of Rome, and the only force that could make such expansion possible was the sons of landless peasants.

Further, there is the question of economic decline. As Rome was preindustrial, the economy consisted mainly of agriculture. Many scholars link the regression of Roman agriculture and of the state with the spread of latifundia. The thesis that the decline of Rome stemmed from depopulation and the growth of latifundia has a long pedigree (Rostovtzeff).

Pliny maintained that the latifundia had destroyed first Italy and then the provinces (NH 18,35). The ancient writers, in their references to the latifundia, depicted desolation in lieu of the prosperity that had once prevailed. Columella described latifundia that had been abandoned, trampled down by cattle or wild beasts and cultivated by slaves in the stocks (Col. 1,13,12.). In sources dating to before the Common Era, latifundia are mentioned only in Varro's «Rerum rusticarum libri tres» (Three Books on Agriculture) $(1,13,3 ; 1,22.2)$. The sources of the first century $\mathrm{CE}$ provide much more information on the latifundia, which are universally considered to be harmful (for example, $\mathrm{NH} \mathrm{18,} \mathrm{17-19,} \mathrm{35;} \mathrm{Col.} \mathrm{1,3,12).}$

Thus, we have solid grounds for saying that the spread of latifundia in Italy began during the first century CE, just after the first large wave of emigration. The large estates were a result of depopulation, because they were formed where there had previously been many peasant's plots. Here I want to draw the attention of the reader to the fact that in Greece in the $3^{\text {rd }}$ century AD after migrations to the territories conquered by Alexander, small peasant possessions were also absorbed by large landowners. True, Greece did not have such large latifundia as in Italy, but arable land in Greece is much smaller.

Just as in Greece, in Italy there was no one to handle these large land holdings. It was impossible to hire farm labourers, since the critical coefficient fell and there was enough land for all. Therefore, in Italy, the latifundia were cultivated by slaves, as the Roman authors reported. This was made possible by victorious wars and a large number of prisoners, but the mass of slaves in rural areas became too large, which led to large slave uprisings.

To be sure, part of the depopulation of the countryside consisted in people moving to towns, especially to the city of Rome, but the main cause was emigration. Scholars have long supposed that the depopulation of Italy was due to emigration (See, for example Luzzatto 2005, 5-6), but they have not generally been able to determine the cause of the emigration. Taking account of the higher productivity of labour under a regime of more extensive farming, the reason for the Italian population's emigration to the provinces becomes evident. In the provinces the critical coefficient was much lower, land was much more readily accessible, and the migrants could obtain more land and practice more extensive agriculture. As a result they worked less.

Certainly, in the first half-century CE the depopulation of Italy was just beginning. But by the second half of the century it had become plain to see. Pliny the Elder wrote that near Rome "The low price of property through all the districts just outside the city in every direction is notorious" (NH, XIV, 5, 50). That was possible only because depopulation had decreased the demand for land. 
The falling critical coefficient diminished all the activities of the Italian population, including military service. Now the bulk of the Roman legions, and their most effective units, were made up of provincials (Tac. Ann, III, 40). Consequently, the crisis of central power ensued, during the so-called "Year of the Four Emperors" (69 CE). However, the crisis was quickly overcome; a significant detail: it was the eastern provinces that proclaimed Vespasian as Emperor. This was one of the first signs that the Eastern part of the Empire was in better condition.

By the late first and early second century, the regression in all spheres of life was growing more and more evident. Pliny the Younger received his rent not in money but in kind, because his tenants were seriously in arrears even though he offered them very substantial abatements (Ep. IX, 37, 3-4). Pliny's tenants could not sell their crops to pay the rent, because demand for farm products was diminishing. That is, at this time market relations had begun to decline.

It is worth remarking that the depopulation came first in the South of Italy, where the capacity of reservoirs was minimal (recall that by the second law, processes in small reservoir are always faster). Depopulation and decline then spread to central Italy. The depopulation of the plain of the Po did not begin until after the second century (Luzzatto, 2005, 6). Earlier, under Julius Caesar and Augustus, Italics had migrated to the Padan plain, making this the most highly developed and prosperous area in Italy towards the end of Augustus' reign, as contemporary authors noted (Tac. Hist. II, 17; Polyb. II, 15).

By the beginning of the second century $\mathrm{CE}$, the human resources of the Empire were exhausted. The Trajan conquests were the last, and from Hadrianon the Empire could do no more than defend itself. At this time, moreover, Rome was in the throes of a deepening economic crisis. Luzzatto suggests that the causes were competition from the provinces (here he agrees with Rostovtzeff), a reduction in the supply of slaves, and oppressive taxation (Luzzatto, 2005, 1-3).

I disagree with all three points. First, competition from provinces could not have caused the depopulation. Since as in all preindustrial societies the majority of the population practiced subsistence agriculture, imports of cheap goods from the provinces could not ruin them. And as Luzzatto himself observes, only after 200 CE do we hear of Gaul exporting wine, (Luzzatto, 2005, 4) and by this time Italy was already in in deep decline. Rather, the imported wine was a substitute. Second, the slaves too were only substitutes, taking the place of free labour. It is hardly necessary to prove that free labour is more effective than slave labour. The patricians were only obliged to turn to slave labour because emigration and the fall of the critical coefficient had made it impossible for them to hire wage labourers. And third, there is no example in all of world economic history of taxation ruining an entire country without sparking popular uprisings.

This entire account of the crisis corresponds to our third law of reservoirs. Economic decline and the political passivity of the populace were accompanied by the weakening of central power. By the end of the $2^{\text {nd }}$ century economic decline (Bernardi, 32) and the instability of the Roman emperors had become evident. Civil war lasted, with some intervals of peace, from 193 to 285 . The depth of the political crisis was in 268-285, with the Empire splitting into three competing states.

The falling critical coefficient radically altered the nature of the Roman army. Before the reform of Marius, it had been a home guard. Afterwards it became an army of the landless sons of peasants compelled to join the army to avoid starvation. Upon retirement, they were given a plot of land. By the second century $\mathrm{CE}$ there was an abundance of free land. We know from Tacitus that veterans often abandoned the land they had been allotted and did not want to be farmers (Ann. IV, 27). The army was now a force of mercenaries, who did not want to work. 
The only reason for the population to support the army was the barbarian threat, which had become menacing indeed. It is well known that an external threat strengthens the power of the state, and in fact despite the declining critical coefficient, the power of the emperors was building. But the sole basis of this power was the army. The emperor Severus accordingly advised his sons to enrich the soldiers and despise the rest. Herodian thought that Severus weakened the strict discipline of the soldiers and their respect for their superiors by teaching them to covet money (III, 8, 4). Later the emperors' dependence on soldiers only intensified. The structure of the army changed in this period, as soldiers were allowed to marry and settle in their own houses. Where previously only veterans had been allotted land, and only after 20 years of service, land was now available to all. So by the time of Constantine the army was composed of frontier garrison troops and mobile field forces. Given the declining motivation of the Roman soldiers, the frontier garrison troops had to defend their own homes and families, and with them the entire Roman Empire.

By 285 the profound political crisis had been overcome. The emperor had become an autocrat, but the economic crisis only worsened (Bernardi, 25). The decline in market relations resulted in constant budget deficits, as it made it much more onerous to pay taxes, even if the nominal sum of taxes did not increase. To finance the deficit, the emperors debased the currency. Between the mid-second and mid-third century the silver content of the denarius was reduced by $46 \%$ (Harl, 127, table 6.1). The debasement continued later and so did inflation. The proclamation of Diocletian's Edict on Maximum Prices showed that the emperors had no real instrument to stop economic decline. It was impossible to fix prices when the debasement of the currency continued. Certainly, the regress of the Empire could not be stopped by any sort of administrative measure. An especially striking example of the impotence of the state was the restrictions placed on social and professional mobility by Diocletian and afterwards by Constantine, which sought to bind every man to his occupation and make it hereditary from father to son (Luzzatto, 2005, 9). Our theory predicts that a decline in the critical coefficient will inevitably produce social regression and the destratification of society. The attempt to preserve the social structure was vain; regression resulted in backward development. The population moved from towns to villages, industry and trade declined.

Another major development was the barbarization of the army. The motivation for Romans to perform military service had totally collapsed. Free lands were abundant, so why risk one's life? The situation of the barbarians, with their high critical coefficient, was quite different. They willingly joined the Roman army, and this process went on until practically all the soldiers of the Roman legions were barbarians.

It is impossible that such sweeping changes to the Roman military and Roman society could have been due to the rise of the Sassanian empire, as some scholars propose (Heather, 62, 67). The Sassanids were successors to the Parthian empire, which had long been a dangerous enemy but had never provoked such profound changes within Rome. Nor did the Sassanids ever threaten the existence of the Roman Empire, and the span of time during which they scored some military victories over the Romans was relatively brief (about 50 years), so the consequences of their actions were necessarily limited in both time and space. Like Mesopotamia, Persia was one of the world's very first civilizations, and by the third century CE these areas had long since been in the stationary state. As usual in such societies, population oscillated around the critical density. When the density increases, the state should strengthen and its war-making should increase, in accordance with the third law of reservoirs. And this scenario corresponds precisely to the historical facts: in this period the number of settlements between the Tigris and the Euphrates increased by 50 per cent (Heather, 61-62) hence the population was in the rise. 
Probably the migrations from peninsular Italy to the Padan plain at the turn of the first century CE were followed by migrations out of Italy and out of Spain and other Mediterranean lands to Gaul and the Rhine valley. In the first half of the 2nd century the migrations were routed to the north of the Balkan peninsula, in the valley of the Danube. The migrants from regions with intensive agriculture and correspondingly high levels of development did not switch immediately to more extensive farming in the new lands where this was feasible. This change was ineluctable, but it would necessarily take some time. First the migrants had to see that more extensive agriculture ushers in higher labour productivity. Also, it is possible that the migrants settled in compact clusters on the best land, enabling them to preserve their agricultural tradition much longer. Therefore, the regression was relatively slow. In the fourth century the stabilization of the situation is evident (Bernardi, 4344). But towards the end of the century another wave of more extensive agriculture got under way, and the crisis consequently intensified. The economic situation worsened (Bernardi, 25), political instability reached peak intensity, the barbarians invaded Roman territory and sacked Rome. The deterioration of Roman society is visible in many spheres. For example, archaeologists have found that villas as a type of settlement disappeared from the $350 \mathrm{~s}$ on in Britain and Northern Gaul and from the fifth century even in the Mediterranean (Wickham, $2005,177)$. This can be read as a sign of social destratification.

Significantly, in Italy it was the Padan plain, the most capacious part of the country, that retained its population for the longest time. Certain towns in northern Italy, such as Milan and Aquileia, Padua and Ravenna, continued to prosper in the first half of the fifth century. For a period of a century, until 404, Milan supplanted Rome as the seat of imperial government and was surpassed by Aquileia (Luzzatto, 2005, 12). Only after the depths of depopulation had been reached was the capital of the Western Empire finally transferred to Ravenna, owing not to its economic importance but to its safe location.

Again, some particulars are significant: Diocletian ruled from the eastern part of the Empire, and Constantine transferred the capital to the East. This was no mere coincidence. The Eastern Empire was doing much better than the West and survived much longer. Our proposed model illuminates the reason for this difference. The Eastern Empire consisted of the former state of Alexander the Great. Greeks and Macedonians had migrated from their native lands to the newly conquered territories. These processes had lowered the critical coefficient in Greece and Macedonia and caused the regression that facilitated the Roman the conquest of those lands. And the relatively low critical coefficient in the Eastern part of the Empire discouraged mass emigration from it. Therefore, in the East depopulation did not occur and regression was weak or even avoided. The reservoir there did not fill up until the time of Justinian, allowing him to undertake the conquest of the lands of the Western Empire.

Archaeological studies have found that the high point of development of settlements in many parts of the Eastern Empire came in the fifth and sixth centuries, followed by contraction in the seventh and eighth (Wickham, 2005, 148-149). In the Balkans, after the seventh century rural settlements are very hard indeed to track (Wickham, 2005,164). Archaeologists and historian agree that there was a crisis in urbanism in the Byzantine lands in the seventh century. Some towns were abandoned and while in other urban areas were contracted (Wickham, 2009, 353). In short, the demographic trend corresponds to political and economic developments. In the western Mediterranean, by contrast, the development of settlements appears to have been relatively continuous, with no peak in the fifth and sixth centuries (Wickham, 2005, 400). This suggests that there was not a generalized population decline in the Roman Empire but a redistribution of population from the Mediterranean to the Northern provinces.

One of the oldest and still widespread theories about the causes of the fall of the Western empire is that the empire was destroyed by barbarians. Indeed, the barbarians seized 
the territory of the Western Empire and established their kingdoms there. However, for many scientists it is obvious that the conquest of the empire by the barbarians became possible only because of its deepest crisis. We have considered the causes of the crisis above and have shown why the events in the Eastern Empire developed differently and why the Eastern Empire resisted the onslaught of the barbarians.

Thus the five cases of regression considered so far share a number of features.

Decline was endogenous. Mass migrations were evident and have been recognized by many experts. Yet practically no one posits that these populations had left their land permanently of their own free will. To my way of thinking, the reason for an error made by so many scholars lies in the generally accepted thesis that progress is always good for the people. This may be true for contemporary society, but it was not the case in preindustrial society, where the consequence of progress for the bulk of the population was longer and harder toil, more taxes, more superiors, and so on. For them, "progress" was always harmful, and if there was a chance of avoiding progress by migration, they surely took advantage of it.

\section{Literature.}

Alexakha A. (2017), "A model of social progress", The Journal of European economic history, 3:137-213.

Andrews A.P., Andrews E.W., Robles C.F. (2003), "The northern Maya collapse and its aftermath", Ancient Mesoamerica, 14:151-156.

Asthana S. (1982), "Harappan trade in Metals and Minerals", Regional Approach in Harappan civilisation, Delhi, 271-285.

Beloch K.Y. (1880), Das Italische Bund unter Roms Hegemonie, staatsrechtliche und statistische Forschungen, Leipzig

Bernardi A. (2013), "The economic Problems of the Roman Empire the time of its decline", The Economic Decline of the Empires, ed. Carlo Cipolla, Oxford.

Betancourt P.P. (1984), "Dating The Aegean Late Bronze Age with Radiocarbon", Archaeometry, 29(1) pp. 45-49.

Bongard-Levin G.N., Ylyin G.F. (1985), India v drevnosty, Moscow,(Бонгард-Левин Г. Н., Ильин Г. Ф., 1985, Индия в древности, Москва).

Boserup E. (1965), The Conditions of Agricultural Growth, London, Allen and Unwin. Brunt P.A. (1971), Italian man power, 225 BC-AD 14, Oxford University Press

Bryce T. (1999), The Kingdom of the Hittites, Oxford.

Callender G. (1999), The Minoans and the Mycenaeans: Aegean Society in the Bronze Age, Oxford University Press.

Cartlidge P. (1979), Sparta and Laconia. A Regional History 1300-362B.C., London.

Castleden R. (2005), Mycenaeans, Psychology Press.

Chakrabarti D.K. (1979), "Size of the Harappan Settlements", Essays in Indian protohistory, D.K. Chakrabarti, D.P. Agrawal (eds.), Delhi, 205-215.

Desborough d'A. R.N. (1964), The Last Mycenaeans and Their Successors, Clarendon Press. Desborough d'A, R.N. (1972), The Greek Dark Ages, Benn.

Dickinson O.T.P.K. (2004), The Aegean Bronze Age, Cambridge.

Finley M. I. (1970), Early Greece: the Bronze Age and Archaic Greece, Norton. Freeman C. (2014), Egypt, Greece and Rome: Civilizations of the AncientMediterranean, Oxford, 2014.

Friedrich W.L., Kromer B., Friedrich M., Heinemeir J., Pfeifer T. ,Talamo S. (2006), "Santorini Eruption Radiocarbon Dated to 1627-1600 B.C.", Science, 28 Apr., Vol. 312, Issue 5773, 548-549.

Greaves A.M.(2002), Miletos: A history. L.; N.Y. 
Harl K.W. (1996), Coinage in the Roman Economy, 300 BC to AD 700, John Hopkins

University Press

Heather P. (2007), The Fall of the Roman Empire: A New History, Oxford.

Hood S. (1971), The Minoans; The Story of Bronze Age Crete.

Johnson S. A. J. (2016), Why Did Ancient Civilizations Fail? Routledge.

Knipe D. (1991), Hinduism, San Francisco, Harper Collins.

Kraiker W, Kübler K., (1939), „Die Nekropolen des 12 bis 10 Jahrhunderts“, Kerameikos

B.1, Berlin.

Kulke H, Rothermund D. (2004), A History of India, Routledge.

Launaro A. (2011), Peasants and slaves: the rural population of Roman Italy (200 BC to Ad 100), Cambridge University Press.

Lo Casio E. (2001), "Recruitment and the size of the Roman population from the third to the first century B.C.E.", W. Schiedel (ed.), Debating Roman demography, Leiden, 111-138.

Luzzatto G. (2005), An economic history of Italy: from the fall of the Roman Empire to the beginning of the 16th century, Taylor and Francis

Mylonas G.E. (1966), Mycenae and Mycenaean Age, Princeton.

Rostovtzeff M.I. (1926), The social and economic history of Roman Empire, Biblio and Tannen Publishers.

Sahlins M. (1972), Stone age economics, Chicago, Aldine Atherton, Inc.

Sandars N.K. (1985), The Sea People. Wariors of the Ancient Mediterranean 1150 B.C., L.

Schofield L. (2007), The Mycenaeans, Los Angeles, Getty Publications.

Sharer, R. J. Traxler L.P. (2006). The Ancient Maya. Stanford University Press.

Sivertsen B.J. (2009), The Parting of the Sea: how volcanoes, earthquakesand plague shaped the story of exodus, Princeton University Press.

Snodgrass A.M. (1980), Archaic Greece: the Age of experiment, Berkley and Los Angeles.

Snodgrass A.M. (2000), The Dark Age of Greece, Routledge.

Starr C.G. (1961), The Origins of Greek civilisation, 1100-650 B.C., N.Y.

Tartaron T.F. (2013), Maritime Networks in the Mycenaean World, Cambridge.

Toynbee A., (1965), Hannibal's legacy: Rome and her neighbours after Hannibal's exit, Oxford University Press.

Welwei K-W. (2002), Die Griechische Frühzeit. 2000 bis 500 v. Chr.,München.

Wheeler R.E.M. (1959), Early India and Pakistan to Ashoka, N.Y.

Wickham C. (2005), Framing the Early Middle Ages, Oxford. 